\title{
An Examination on the Relationship between Teachers Emotional Intelligence and
}

\section{Students' Motivation}

\author{
* Dr. Fazli Khaliq \\ ** Ghazala Naheed Baig \\ *** Mehnaz Begum
}

\begin{abstract}
The study aims to ascertain the relationship between the emotional intelligence of teachers and students' motivation. The objectives of the study were to; investigate the emotional intelligence faculty, probe into learners' motivation in the teaching space, and to assess the correlation between emotional intelligence (EI) of teachers and the students' motivation. All faculty and learners of Khyber Pakhtunkhwa' nine universities were the population of the research work. 200 teachers and 400 students were taken through the lottery method and convenient selection methods. The data collected from the sample group through Questionnaires and interview the collected data were analyzed through descriptive and inferential statistics. A considerable moderate correlation was noticed between Emotional intelligence (EI) of teachers and students' motivation. It is recommended that teachers may also work on the confidence-building of students where close academic relationship and mutual trust between teachers and students are indispensable.

Keywords: Intelligence; Emotional Intelligence; Motivation, Students Motivation Introduction

The change of any educational system is closely related to the eminence of its teachers and that is why teaching is the most honorable among all professions and the teachers are called the nations' mind makers. However, he can perform his or her various responsibilities well if he or she were professionally and personally efficient (Kumar \& Ritzhaupt, 2015).

The teacher has different tasks while handling a classroom setting. These tasks are classroom management, thorough preparation through lesson plan, application of best teaching methodology, positive interactions with students, and pragmatic approach to the use of EI during instruction procedure (Clotfelter et al, 2005). Emotionally and socially equipped teachers make sure that all learners' fundamental talents and have robust experiences in other disciplines as well as enhance their own and learners' emotional domain. (Greenberg et al, 2003).

EI is a wider construct (Bar-On, 1988, 1997b, 2000). Spielberger (2004) recently suggested that EI has at present three key theoretical prototypes such as the Salovey-Mayer model (Mayer \& Salovey, 1997), Goleman model (1998) and Bar-On model (1997) that describe the aptitude to identify, and comprehend passions, to comprehend relationship with others and to regulate sentiments, and to produce a constructive effect.

Encouragement is a fundamental aspect of teaching and learning (Brewer \& Burgess, 2005). But what really motivation is? Ryan and Deci (2016) believe that motivation is to perform something. If an individual gets no motivation is considered unmotivated. Similarly, motivation has also been defined by Crump (1995). He noted that 'Encouragement, interest, and enthusiasm are the key components of motivation'. For students to be academically successful, motivation is of utmost importance. Ryan and Deci (2016) suggest that inspiration is not a sole sensation, rather persons not only have diverse sums of motivation but diverse levels of inspiration'. For instance, a student could be highly motivated because he/she would want to learn and discover new knowledge or understand a
\end{abstract}

\footnotetext{
* National College of Physical Education Mardan Email: khaliq78@ yahoo.com

** Department of Education, Abdul Wali Khan University Mardan Email: ghazala@awkum.edu.pk

*** Email: mehnaz.education@yahoo.com
} 
phenomenon at hand. While at the same time another student may be highly motivated just because he/she wants to appease the teacher.

\section{Research Objectives}

The Research objectives were;

1. To investigate emotional intelligence (EI) of teachers at university.

2. To find out students' motivation in universities

3. To ascertain the correlation between emotional intelligence of teachers and students' motivation.

\section{Research Questions}

1. What is teachers' emotional intelligence at the university level?

2. What is the motivation level of learners at the university in the classroom learning environment?

3. Is there a correlation exist of teachers' emotional intelligence (EI) with the motivation of students?

\section{Literature Review}

What is emotional intelligence? How to apply it? In which context it may be used? These were the questions that forced researchers to define and give a description of the EI construct. Among the researchers, Mayer, Salovey, and Caruso (2004) distributed emotional intelligence into four divisions viz.: the aptitude to feeling and sentiments, practice feelings and sentiments to augment thought, understand feelings, and sentiments, and regulate feelings and sentiments. It is emphasized by other intellectuals that open and restricted behavior toward experience also specifies a person's emotional intelligence (McCrae, 2000). In the same way, Mayer, Salovey, and Caruso (2008) admitted extensive deficiencies in knowledge and defining emotional intelligence although ambiguous in reading talk over emotional intelligence correctly and inadequate facts and investigational work just hint to the emotional intelligence construct. Psychosomatic qualities such as the necessity for success, the strength of mind, strength of will, contentment, and will power should be well-defined, assessed, and construed distinctly rather than mingling them up and counting them emotionally intelligent (Mayer et al., 2008). The explanation additionally elucidates and highlights the extensive and diverse effects of emotional intelligence. Nonetheless, emotional intelligence needs to be streamlined, cut down, and reconcentrated as it still wants a strong and vibrant and unanimously accepted description, explanation and classification; and is taken to mean differently by social scientists (Arghode, 2014).

Perhaps, emotional intelligence's distinction is because of its association with learning, achievement, or aptitude to forecast upcoming performances. This point is backed by investigators who assign emotional intelligence for management skills and job presentations (Watkin, 2000). Another model of EI stretched out the meaning of EI to comprise qualities of trustworthiness, reliability plasticity, expressiveness, group fitness, and combined proficiencies (Mayer et al., 2008). Edmond-Kiger et al.'s (2006) work noted variances in EI.

EI is nascent for a new-fangled aptitude construct. Salovey and Mayer (1990) introduced it. Later on, it faced so many challenges and continuous contentious consultations and hot debates but its efficacy is still interrogated even these days (Landy, 2006). Someone called it SI, someone emotional intelligence and even Goleman (2006) described it as the new-fangled science of human interactions.

Wiggin (1973) introduced psychometric intelligence which grounded on psychological and social paradigms. According to Weber and Westmeyer (2001), psychologists called it academic intelligence or psychological assessment. Later on, this construct was called emotional (Salovey \& Mayer, 1990), practical (Wagner \& Sternberg, 1985), or successful intelligence (Sternberg, 1997) as a new ability constructs.

The Emotional intelligence (EI) construct was first made known a hundred years before. It was also recognized that the intellectual endeavour has done by Thorndike (1920) on social intelligence (SI) was the most basic effort on emotional intelligence (Bar-On, 2006; Gardner, 1983). Gardner (1983) anticipated the manifestation of dissimilar kinds of intelligence in persons containing the conceptualizations of interpersonal intelligence (EI) and intrapersonal intelligence (SI). Interpersonal Intelligence is the ability of perceptive, appreciative, handling, and responding to feelings, sentiments, excitements, passions, and sensations in others. EI is the aptitude of appreciation, consideration, management, and retorting to one's emotional state sentiments, excitements, passions, 
and sensations. Gardner (1983) believed that these kinds of brainpower are as significant as the kind of brainpower characteristically determined by Intelligent Quotient (Petrides, 2011). The readings provide a base for the creation of Emotional intelligence that is new terminology for the researchers.

Salovey and Mayer (1990) familiarized the construct of EI, which gained fame after the book of Goleman in which he said the EI has more strength than IQ. After this, the researchers introduced the new notion, theories, and model about emotional intelligence. The most prominent models among these were ability models, trait models, and mixed models. The first one deals with mental abilities, the second one is related to intellectual abilities for solving emotional glitches (Fernandez- Berrocal \& Ruiz, 2008).

Spoken aptitude, retention, and dispensation capability features of intelligence are respectively the same to the emotional intelligence individualities of ability to overcome emotional state and employing emotional state to improve intelligence (Mayer et al., 2008). EI plays an essential role in the behavior of a person, performance, enactment, and capability to deal with unforeseen events. Emotional intelligence also influences a person's aptitude to interconnect emotional state and frame of mind efficiently, successfully, correctly, and perfectly. The dearth of emotional intelligence frequently shows unwanted attitudinal and societal results.

To make clear the dissimilarities in brainpower and its application, Fer (2004) clarified even though 'IQ tests may assess analytical and verbal aptitude well, they are not an accurate test of creativity, of practical knowledge, and other skills involved in problem-solving' (p. 565). Thus just having intelligence does not give assurance of achievement in the allocated responsibilities. Moreover, intelligence is the capability to make an impression on both psychological and somatic good fortune (Kotsou et al., 2011). Emotional intelligence also changes social communications and influence work capability. Kotsouet al. (2011) emphasized numerous profits of emotional intelligence for groups and individuals ranging from lesser work-related stresses, behavioral glitches, attitudes, talent to lead, joint enthusiasm, job satisfaction, and a greater sense of possession, commitment, and faithfulness with the group. In reality, identifying social and emotional intelligence is supportive of forecasting job performance (Cherniss, 2010).

Motivation is the name of inspiration. To set other individuals for good performance is the real motivation. It also an individual approach towards something and to achieve great success in any field. It is assistance on the part of the teacher or motivator for students to prepare him/her for super achievements. It is the refinement of the mind and actions of the learner (Kamsi, 2008). The extent of inspiration will regulate the efficiency of students' actions (Sapran, 2010). Inspiration has an emotional impact on learners. It ensures advancement on the part of students. It energizes the student for the accomplishment of goals. It improves performance. There are two kinds of motivation i.e. individual and joint motivation. Sometimes individual teachers inspire a student and prepare him/her for the achievement of the targets. But sometimes two or more than two personalities stir the emotions of the individual and prepare the attainment of the task (Ganaie, \& Mudasir, 2015). The role of motivation has paramount importance in the way of success. After motivation, the student gets energy and enthusiasm and then he can easily get his target. A relationship between persons grounded on enactment. So, the inspiration for learners is considered an important dimension for learners' enactment (Elenkov, 2002).

\section{Methodology}

A mixed-method explanatory sequential design was used. Faculty and learners of four both sector higher institutes of Khyber Pakhtunkhwa (KP) were the populations of the research work. According to HEC and development statistics Khyber Pakhtunkhwa (2017), there are (1232) teachers and (25640) students in four both sector higher institutes KP. Judgmental and lottery methods were adopted to choose the respondents. The sample size was 900 faculty and leaners. The questionnaire was used for quantitative data and interviews were conducted for qualitative data.

\section{Analysis of the Data}

R.Q.1:- What is the emotional intelligence of university teachers?

Table 4.1

University teachers' emotional self-awareness

\begin{tabular}{clrc}
\hline Serial no & Items & Mean & $\begin{array}{l}\text { Std } \\
\text { deviation }\end{array}$ \\
\hline 1 & I can recognize my emotional related weaknesses. & 3.94 & .870
\end{tabular}


I easily recognize my emotional strengths.

$4.01 \quad .868$

I know my weaknesses and freely share them with co-workers.

$3.91 \quad .912$

I know my innermost feelings

$4.01 \quad .868$

I know my connection affected by my sentimentalism

$4.01 \quad .868$

I know different dimensions of my emotions

$4.01 \quad .868$

I am keen to identify my bad feeling about something

$4.01 \quad .868$

I feel weakness when I am worried

4.01

.868

Overall

3.99

.873

Table 4.1 describes that participants gave consent on self-awareness as a construct of emotional intelligence as shown by their individual as well as overall mean scores $(3.94,4.01,3.91$, $4.01,4.01,4.01,4.01,4.01$ and 3.99). in the same way, the std figures mirror that most of the participants are undivided in viewpoints concerning the items relating to self-awareness as a construct of EI.

Table 4.2

Self-management in teachers

\begin{tabular}{clcr}
\hline $\begin{array}{c}\text { Serial } \\
\text { no }\end{array}$ & Items & Means & $\begin{array}{l}\text { Std } \\
\text { deviation }\end{array}$ \\
\hline 1 & I show confidence in difficult situations. & 3.92 & .912 \\
2 & I monitor my actions during teaching & 3.55 & 1.03 \\
3 & I dare to control my emotions in an adverse situation & 3.91 & .912 \\
4 & To boost my confidence I come to class well prepare. & 3.98 & .919 \\
5 & I can manage my emotions relating to students. & 3.96 & .961 \\
6 & I am respectful to students but limited & 3.73 & .907 \\
7 & I often feel distressed when learners instigate me & 3.94 & .869 \\
8 & I utilize my spare time efficiently & 4.01 & .867 \\
& Overall & 3.87 & .922 \\
\hline
\end{tabular}

The above table (4.2) describes that participants gave consent to self-management as a construct of emotional intelligence as shown by their individual as well as overall mean scores (3.92, 3.55, 3.91, 3.98, 3.96, 3.73, 3.94, 4.01 and 3.87). Moreover, the standard deviation figures reproducer that all the participants are restricted in viewpoints relating to self-management as a construct of EI.

Table 4.3

Teachers' social awareness

\begin{tabular}{|c|c|c|c|}
\hline $\begin{array}{c}\text { Serial } \\
\text { no }\end{array}$ & Items & Mean & $\begin{array}{l}\text { Std } \\
\text { deviation }\end{array}$ \\
\hline 1 & I can handle the emotions of mine while dealing with others. & 4.01 & .869 \\
\hline 2 & $\begin{array}{l}\text { I have an emphatic feeling about others' problems and try my best to } \\
\text { solve them. }\end{array}$ & 4.01 & .869 \\
\hline 3 & I show confidence in community-related situations. & 4.01 & .869 \\
\hline 4 & $\begin{array}{l}\text { I recognize my passions which influence the relation of mine with } \\
\text { learners }\end{array}$ & 4.02 & .863 \\
\hline 5 & I try to guarantee that my teaching is ethnically susceptible & 3.96 & .859 \\
\hline 6 & I regularly understand the actions of students & 4.08 & .938 \\
\hline 7 & I know the feelings of learners & 3.96 & .859 \\
\hline 8 & $\begin{array}{l}\text { I distinguish how others experience by looking at their facial } \\
\text { expressions. }\end{array}$ & 4.02 & .863 \\
\hline & Overall & 4.01 & .873 \\
\hline
\end{tabular}

Table 4.3 describes that participants gave consent on social-awareness as a construct of emotional intelligence as shown by their individual as well as overall mean scores $(4.01,4.01,4.01$, 4.02, $3.964 .08,3.96,4.02$ and 4.01). Furthermore, the STD figures represent that majority of the participants were undivided in viewpoints regarding items relating to social awareness as a factor of EI.

Table 4.4

Teachers' social management

\begin{tabular}{clrc}
\hline $\begin{array}{c}\text { Serial } \\
\text { no }\end{array}$ & Items & Mean & $\begin{array}{c}\text { Std } \\
\text { deviation }\end{array}$ \\
\hline 1 & I am straight-forward with others. & 4.33 & .821 \\
2 & I admit my mistakes to others. & 3.94 & .830 \\
3 & I increase in value others' hard work in launching decent associations. & 4.14 & .886
\end{tabular}


4 I frequently make judgments and don' care about its effect.

$\begin{array}{ll}4.32 & .826 \\ 4.11 & .885 \\ 4.15 & .886 \\ 3.86 & 1.03 \\ 4.08 & .934 \\ 4.13 & .856\end{array}$

5 I show calmness when others disturb me

26

I take criticism without getting angry

.885

Ideals positively with ethnic learners

1.03

I treat all students equally

.934
856

Table 4.4 refers to that participants gave consent on relational management as a construct of emotional intelligence as shown by their individual as well as overall mean scores $(4.33,3.94,4.14$, 4.32, 4.11, 4.15, 3.86, 4.08 and 4.12). Moreover, the STD figures represent that the participants were undivided in viewpoints regarding the items connecting to interpersonal management as a factor of EI.

R Qs 2 Is their motivation of students to exist at the university level in the classroom learning environment?

Table 4.5

Motivation among university students

\begin{tabular}{clcc}
\hline S No & Items & M & Std \\
\hline 1 & The teacher is optimistic about the work matter in class. & 3.95 & 0.98 \\
2 & I inspire from my teacher in class. & 4.19 & 0.96 \\
3 & I am fully involved to inspire my students. & 4.53 & 0.68 \\
4 & Learning new skills excite me in class. & 4.55 & 0.67 \\
5 & I value the chance that makes me able to discern my strong and weak & 3.97 & 0.85 \\
& points in class. & 3.84 & 0.90 \\
6 & I get confidence from my teacher in class. & 3.78 & 1.04 \\
7 & The teacher inspires me to do good work. & 3.91 & 1.02 \\
8 & I get motivated when my teacher uses rewarding words & 4.17 & 0.83 \\
\hline
\end{tabular}

Table 4.5 describes that participants gave consent on motivation as a construct of the classroom learning environment as shown by their individual as well as overall mean scores (3.95, $4.19,4.53,4.55,3.97,3.84,3.78,3.91$ and 4.17). It is clear the students at the university level can get support from their teachers in their activities for creating a congenial learning environment and believe that teachers' support is one of the best constructs of the learning environment. It is further indicated that there is the motivation among students in the classroom which is very helpful in their learning.

R.Q 3. Is there a correlation exist of teachers' emotional intelligence (EI) with the motivation of students?

Table 4.6

Pearson Correlations of EI components with Motivation

\begin{tabular}{|c|c|c|c|c|c|c|c|}
\hline & & $\begin{array}{c}\text { Correlations } \\
\mathbf{M}\end{array}$ & & SA & SM & SOA & $\mathbf{R M}$ \\
\hline \multirow{4}{*}{$\begin{array}{l}\text { Students } \\
\text { motivation }\end{array}$} & Pearson Correlation & & - & $.703^{* *}$ & $.731^{* *}$ & $.681^{* *}$ & $.912^{* *}$ \\
\hline & Sig. (2-tailed) & & & .000 & .000 & .000 & .000 \\
\hline & $\mathrm{N}$ & & & 900 & 900 & 900 & 900 \\
\hline & Pearson Correlation & & & - & $.731^{* *}$ & $.730^{* *}$ & $.702^{* *}$ \\
\hline \multirow[t]{2}{*}{ Self-awareness } & Sig. (2-tailed) & & & & .000 & .000 & .000 \\
\hline & $\mathrm{N}$ & & & & 900 & 900 & 900 \\
\hline \multirow{4}{*}{ Self-management } & Pearson Correlation & & & & - & $.681^{* *}$ & $.751^{* *}$ \\
\hline & Sig. (2-tailed) & & & & & .000 & .000 \\
\hline & $\mathrm{N}$ & & & & & 900 & 900 \\
\hline & Pearson Correlation & & & & & - & $.671^{* *}$ \\
\hline \multirow{3}{*}{ Social awareness } & Sig. (2-tailed) & & & & & & .000 \\
\hline & $\mathrm{N}$ & & & & & & 900 \\
\hline & Pearson Correlation & & & & & & \\
\hline Relational & Sig. (2-tailed) & & & & & & \\
\hline $\begin{array}{l}\text { management } \\
* * \text {. Correlation is }\end{array}$ & $\begin{array}{l}\mathrm{N} \\
\text { significant at the } 0.01\end{array}$ & tailed). & & & & & 900 \\
\hline
\end{tabular}


The overhead table demonstrates that parameters of EI correlate with learners' motivation (Rvalue $.703,731, .681$ and .912 ) which shows significance at .000 while small relationship for social awareness. So, a (.671) and large correlation was noted for interpersonal management (R-value .912) which shows significance at .000 .

RQ. 3: Is there a correlation exist of teachers' emotional intelligence (EI) with the motivation of students?

Table 4.7

Pearson Correlations between Emotional Intelligence and Learners Motivation

\begin{tabular}{|c|c|c|c|}
\hline \multicolumn{4}{|c|}{ Pearson Correlations } \\
\hline & & $\begin{array}{c}\text { Teachers emotional } \\
\text { intelligence }\end{array}$ & Students motivation \\
\hline Emotional intelligence & $\begin{array}{l}\text { Pearson Correlation } \\
\text { Sig. (2-tailed) } \\
\text { Pearson Correlation }\end{array}$ & - & $\begin{array}{l}.492^{* *} \\
.000\end{array}$ \\
\hline Students motivation & $\begin{array}{l}\text { Sig. (2-tailed) } \\
\mathrm{N}\end{array}$ & & 900 \\
\hline
\end{tabular}

The association of EI with Motivation was scrutinized by smearing the Pearson correlation coefficient. Average association of both variables, $r=.492, n=900, P<.000$, not as much of .05 indicating the statistical significance of the results.

RQ. 3: Is there a correlation exist of teachers' emotional intelligence (EI) with the motivation of students?

Table 4.8

Sector-wise relationship of teachers' Emotional intelligence with student's motivation in both sector universities

\begin{tabular}{lcccccc}
\hline & & \multicolumn{2}{c}{ Correlations } & & & \\
\hline & $\begin{array}{l}\text { Type of organization } \\
\text { (binned) }\end{array}$ & $\mathrm{N}$ & Mean & Std deviation & $\mathrm{r}$ value & Sig. level \\
$\begin{array}{l}\text { Teacher } \\
\begin{array}{l}\text { Emotional } \\
\text { intelligence }\end{array}\end{array}$ & public & 450 & 132.8170 & 6.93612 & .368 & .000 \\
$\begin{array}{l}\text { Students } \\
\text { motivation }\end{array}$ & & & & & & \\
& Private & 450 & 124.0424 & 13.86052 & .601 & .000 \\
\hline
\end{tabular}

**. Correlation shows significance at the 0.01 level (2-tailed).

The overhead table demonstrates the mean, STD on, Pearson product correlations, and importance of the EI and students' motivation from the sector-related viewpoint. The mean score of the EI with learners' motivation. in both sector universities was 132.8170 and 124.0424 with an STD of 4.93612 and 13.86052. The $\mathrm{r}$-value shows is $(\mathrm{r}=.368)$ average correlation at significant level $(.000)$. The $\mathrm{r}$ value is $(\mathrm{r}=.601)$ demonstrates large correlations at significant level $(.000)$. The values display that the association of EI with student motivation is better in private sector universities.

Consequently, the large correlation was found in the public sector and the average association was noted in the public sector generally, the paper grants a vibrant account of domino effect gotten from the gathered data.

Findings

1. The mean score (3.99) displayed the faculty was well-conversant with the aspect of selfawareness of EI (Table 4.1).

2. The total mean score (3.87) revealed that faculty were self-managed- the aspect of EI (Table 4.2).

3. The whole mean score (4.01) exhibits social awareness of faculty members- the concept of EI (Table 4.3).

4. Most of the respondents believe in relational management as a parameter of EI as exposed by the total mean score (4.13). (Table 4.4)

5. The total mean score (4.17) presented that students' motivation is a necessary aspect of the classroom learning environment (Table 4.5). 
6. The $\mathrm{r}$ values $(.703, .731 .681, .672$ and .912$)$ indicated large association of EI with students motivation, shows significance at .000 (Table 4.6).

7. The r-value (.492) which showed significance at .000 medium relationships of EI with students' motivation. (Table 4.7).

8. The r-value (.368) which exposed significance at .000 indicated medium association in the public sector and R-value (.601) exhibited a large relationship in private sector universities of EI with students' motivation. (Table 4.8)

\section{Conclusion}

1. It is concluded from the findings of the study that most of the faculty members were wellaware of self-awareness as a concept of EI

2. It was deduced that the majority of the faculty members were found a high level of EI

3. It is also deduced that the majority of the faculty members were self-managed

4. It was also deduced from findings that most of the teachers were socially strong in the social connection with students

5. It was also inferred that most of the faculty members were strong in relational management

6. It was also deduced from the findings that students' motivation has a large relationship with all the parameters of EI.

7. It was also deduced from the findings that students' motivation has a large relationship with all the parameters of EI in private sector higher institutes.

8. It was also deduced from the findings that students' motivation has a medium relationship with all the parameters of EI in public sector higher institutes.

9. Most university teachers have an above-average level of EI. Respondents were satisfied with their motivation in the classroom learning environment. A significant moderate correlation was noted between the EI and learners' motivation at the university level. Male university teachers' emotional intelligence was higher than female teachers No significant differences were found in private sector participants and public sector participants in Emotional Intelligence. Major themes of EI are awareness of the self, awareness of the society, management of the self, and management of the others and were found from the views of the

\section{Discussion} informants that EI of faculty members significantly affects learners' motivation.

It is shown by the literature that highly socially intelligent persons are especially sociable, caring, kind, considerate, more adjustable, and well-organized in coping with several societal matters and prosperous in society (Birknerová, Frankovský, \& Zbihlejová, 2013). These two studies favor finding no. 1, 2, 3, and 4 of the study. Emotional intelligence has been also connected to constructive results (Birknerová et al., 2013) supports the results of the research work. The studies of Nagra, (2014); Saxena and Jain (2013) favor these findings by finding professed reputation significantly linked with Emotional intelligence, and disfavouring by positing no link between educational performance and emotional intelligence. An emotional state of mind has an emotional impact on instruction (Palomera, Fernandez- Berrocal, \& Brackett, 2008) supports the findings. Goleman, Boyatzis \& Rey (1999) study favors the qualitative emerged themes of the study i.e. self-regulation, social skills, empathy, etc. Labbaf, Ansari \& Masoudi (2010) have shown a direct and positive association of EI with knowledge gaining magnitudes, as well as showing the influence of EI on the knowledge gaining magnitudes that supports the findings. The results of research applied by Habibian (2006) showed a direct and large correlation of EI and learning environment; Josmann (2006) suggested the positive and noteworthy association of EI with working values of workers fully favor the outcomes of this research work. BarOn (1997) believes there exists a positive relationship among the branches of emotional intelligence support the findings. The results of the study of Igbinovia (2016) and Okpara and Edwin, (2015) favor the findings of this study.

\section{Recommendations}

1. Based on conclusion No 1, as the teachers at universities have above average level Emotional intelligence which was confirmed by the interview data too. Therefore, it was recommended that they may utilize their EI for enhancing students' Emotional intelligence as the interview data revealed that the majority of students were unaware of EI, through direct counseling sessions and awareness seminars. 
2. The conclusion No 3 provide a pragmatic proof of the relationship of EI with students' motivation which enables the researcher to recommend that teachers may provide training, workshops and awareness seminars on emotional intelligence to enhance the effectiveness of their instruction and to reduce the intentional and unintentional emotional abusing practices in the classroom.

3. Further, it was recommended that teachers may also work on the confidence-building of students where close academic relationships and mutual trust between teachers and students are indispensable.

4. Established on the results of research work it was also endorsed that at the university level there must be a counseling center for teachers and students aimed at the solution of psychological problems and behavioral disorders.

5. For future researchers, it was recommended to design a study to investigate those aspects that directly donate to and affect the progress of the EI of faculty members and learners.

References

Arghode, V. (2014). Emotional and Social Intelligence competence: Implication for Instruction. International Journal of Pedagogies and Learning, 8(2), 66-77. doi:10.5172/ijpl.2013.8.2.66

Bar-On, R. E., \& Parker, J. D. (2000). The handbook of emotional intelligence: Theory, development, assessment, and application at home, school, and in the workplace. Jossey-Bass.

Bar-On, R. (1988). The development of a concept of psychological well-being.

Unpublished doctoral dissertation, Rhodes University, South Africa.

Cherniss, C. (2010). Emotional intelligence: Toward clarification of a concept. Industrial and Organizational Psychology, 3(2), 110-126.

Clotfelter, C. T., Ladd, H. F., \&Vigdor, J. (2005). Who teaches whom? Race and the distribution of novice teachers. Economics of Education Review, 24(4), 377-392.

Brewer, E. W., \& Burgess, D. N. (2005). Professor's role in motivating students to attend class. Journal of STEM Teacher Education, 42(3), 3.

Ganaie, M. Y., \& Mudasir, H. (2015). A study of social intelligence and academic achievement of college students of District Srinagar, J\&K, India. Journal of American Science, 11(3), 23-27.

Gardner, H. (1983). Frames of mind. New York: Basic Books.

Goleman, D. (2006). Emotional intelligence. New York: Bantam Books.

Goleman, D. (1998). Working with emotional int6elligence. New York: Bantam Books.

Greenberg, L. S., \&Paivio, S. C. (2003). Working with emotions in psychotherapy (Vol. 13). Guilford, J. P. (1968). Intelligence, creativity, and their educational implications. Edits Pub. Press.

Kamsi, W. (2008). " Albania" 1897-1909: bibliografí kronologjike. Botime Françeskane.

Lee, J. E., Day, J. D., Meara, N. M., \& Maxwell, S. (2002). Discrimination of social knowledge and its flexible application from creativity: A multitrait-multimethod approach. Personality and Individual Differences, 32(5), 913-928.

Luca, J., \&Tarricone, P. (2001). Does emotional intelligence affect successful teamwork?

McCrae, R. R. (2000). Emotional intelligence from the perspective of the five-factor model of personality.

Mayer, J. D., \&Geher, G. (1996). Emotional intelligence and the identification of emotion. Intelligence, 22(2), 89-113.

Mayer, J. D., \& Salovey, P. (1997). What is emotional intelligence: In P. Salovey, \& D. Sluyter (Eds.). Emotional development and emotional intelligence: Implications for educators (pp. 331). New York: Basic Books.

Mayer, J. D., Salovey, P., \& Caruso, D. R. (2002). Mayer-Salovey-Caruso Emotional Intelligence Test (MSCEIT). Toronto, Canada: Multi-Health Systems, Inc.

Moss, F. A., \& Hunt, T. (1927). Are you socially intelligent? Scientific American, 137, 108-110.

Neubauer, A. C., \&Freudenthaler, H. H. (2005). Models of emotional intelligence. Emotional intelligence: An international handbook, 31-50.

Petrides, K. V. (2011). Emotional intelligence.

Ryan, R. M., \& Deci, E. L. (2016). Facilitating and hindering motivation, learning, and well-being in schools: Research and observations from self-determination theory. Handbook of motivation at school, 96. 
Ritzhaupt, A. R., \& Kumar, S. (2015). Knowledge and skills needed by instructional designers in higher education. Performance Improvement Quarterly, 28(3), 51-69.

Salleh, H. M., Arshad, A., Shaarani, A. F., \&Kasmuri, N. (2008). Cooperative movement in Malaysia. Salovey, P., \& Mayer, J. D. (1990). Emotional intelligence. Imagination, Cognition, and Personality 9, 185-211.

Sapran, A. S. (2010). Exploiting cooperative movement strengths. Palancar, 37(4), 10-11.

Sternberg, R. J. (1985). Beyond IQ: A triarchic theory of human intelligence. CUP Archive.

Thorndike, E. L. (1920). Intelligence and its uses. Harper's Magazine 140, 227-235.

Wechsler, D. (1958). The measurement and appraisal of adult intelligence (4th ed.). Baltimore, MD: The Williams \& Wilkins Company.

Zirkel, S. (2000). Social intelligence: The development and maintenance of purposive

behavior. In R. Bar-On and J. D. A. Parker (Eds.), Handbook of emotional intelligence. San Francisco. 